\title{
Microfinance Helps to Rural Women for Poverty Reduction in the District of Bogra, Bangladesh
}

\author{
Isahaque Ali ${ }^{1, *}$, Muhammad Shariful Islam ${ }^{2}$, Zulkarnain A. Hatta \\ ${ }^{1}$ Department of Sociology and Social Work, Gono University, Savar, Bangladesh \\ ${ }^{2}$ Department of Social Work, University of Rajshahi, Bangladesh \\ ${ }^{3}$ Department of Social Work, Universiti Sains Malaysia, Malaysia
}

Copyright (C) 2015 Horizon Research Publishing All rights reserved.

\begin{abstract}
The primary objective of this study was to examine the role of microfinance programs in poverty reduction among the poor women in Bogra District. The study was based on data collected from a total of 400 microfinance beneficiaries, which was recruited using a simple random sampling in the year 2011. The study findings suggested that there was no significant relationship of microfinance on specific variables such as household income, education opportunities, employment, health, nutrition, sanitations facilities and women's empowerment in the district of Bogra. Only housing status of microfinance beneficiaries had improved during their membership periods. This study proposed a poverty reduction model that includes various aspects including political and social policy reformulations; natural disaster management; employment opportunities;financial assistances; zakat and social safety nets; proper healthcare for the poor; education and knowledge institutions; technical or skills development training; vocational education; development infrastructure and shelter; women's empowerment and capacity building; as well as women's human rights and social justice in order to be more effective in understanding and finding solutions to mitigate poverty in general.
\end{abstract}

Keywords Bangladesh, Microfinance, Poverty Reduction

\section{Introduction}

Multidimensional poverty is a current global issue and nationally exits in Bangladesh. In Bangladesh, the endeavors of formal and informal financial sectors are ineffective to serve the poorer section of the communities [1]. It is also perceived informal financial sectors have failed to help the poor to generate their income and reduce the intensity of poverty. Microfinance is considered as one of the most important programs for poverty reduction. There are larger numbers of microfinance programs executed by
Micro-Finance Institutions (MFIs) to reduce poverty in the country. It is also conceded by a good number of economists and MFIs that the programs are successful in the poverty reduction in Bangladesh. However, it is estimated nearly $45 \%$ of the country's population lives below poverty line [2].The prime objective of the study would be examining the impact of microfinance programs in poverty reduction initiatives in Bangladesh An effective poverty reduction program will only consider the poor as change agents. The poor do not need aid; they need opportunity to get empowered to improve their living standard [3].

The study by Ahmad (2009), approximately 1000 of microfinance institutions and services are in existence and operational in serving 17 million active borrowers in more than total of 85,000 villages in Bangladesh. The largest microfinance sector reaches $37 \%$ of Bangladeshi household, which is amongst the highest coverage in the world [4]. However, the effectiveness of microfinance programs is not considered to improve the living standards of the Bangladeshi poor communities [5,6]. The major part of this study was dedicated to evaluate the microfinance programs in Bangladesh. There was a scope to study the sustainability of short term gains of poor people in Bangladesh. Therefore, this study attempted to evaluate whether the microfinance projects are imperative for poverty reduction in Bangladesh. Amid all these remarks, it is vital to scrutinize the effectiveness of micro-financing initiatives in poverty reduction, with special references to Bangladesh.

\section{Literature Review}

Poverty reduction is being perceived as an enormous challenge in the current global economic arena. Poverty is the most common subject widely discussed and discoursed among academics, politicians, masses, and Bangladesh is a classic example for a poverty ridden country. The empirical evidence of the impact of microfinance and poverty reduction in Bangladesh seems to be very complicated. The available studies recognized that the access to credit by the 
poor have a positive, great and sustainable effect in their living standards. Few other studies demonstrated that poverty has not been reduced by microfinance. They revealed that poor households simply became poorer due to the additional burden of further debt. As reported by Ahmed (2009) all microfinance members were able to increase their household income and improved their living standards [7]. However, Hoque (2004) established that $65 \%$ of the microfinance borrowers remained to be poorest [8].

Rapid growth of microfinance all over the world does not helping to reduce poverty. If societies are serious about helping the poorest of the poor, they should stop investing in microfinance and start supporting large, labor-intensive industries to create employment opportunities for poverty reduction [9]. The interest rates have collected by microfinance institutions are most crucial issues in Bangladesh. They are claiming of interest rates ranging from $30 \%$ to $100 \%$ on an annualized basis $[10,11]$. Murdoch (2008) found in a survey of 350 lending microfinance institutions which charged between $20 \%$ and $40 \%$ annually after taking inflation into account [12]. The study by Mahajan (2005) established microfinance is inevitable but not an adequate provision for poverty reduction overall [13]. Some specific inputs such as exploring of livelihood opportunities, selection and motivation of the micro-entrepreneurs, business and technical training for proper employment are required, he further suggested. If these are not considered, microfinance would be confined to a limited familiar set of activities like small farming, livestock rearing and petty trading. It is also crucial to consider that the success of microfinance has been contradicted by intense criticism, particularly regarding loan repayment, exploitation of female beneficiaries, provision of ineffective microfinance, inconsistency [14].

The study by Pollin (2007) established that the success of microfinance run by poor is impossible [15]. For successful of micro-enterprises business they need marketing support to reach customers. The biting event against microfinance is that it requires to the poor to be entrepreneurial to increase income. In developing countries like Bangladesh, it is much clearer that most people are poor and not entrepreneurial to run their business for profitable.

The study by Banerjee, et al., (2009) established that microfinance for women has no impact on women participants' average monthly expenditure per capita, health, education or their women's decision making in India [16]. There is a risk that microfinance may draw off funds from other microfinance projects that might help the poor [17]. They stated that MFIs, governments and donors should know whether the poor gain more from microfinance than from proper health care or basic needs to improve living standard. Therefore, there is a need for all involved in microfinance and development to ascertain what exactly should be the role of microfinance in combating poverty [18]. In addition, Dichter (2006) recognized that microfinance is helpful to a limited extend in the field of poverty reduction in Bangladesh [19].
There is a comparable view, that MFI services provided to the non-poor could reduce poverty by absorbing very poor people into the labor market as employees of microfinance beneficiaries [20]. However, microfinance is reaching a small portion of the estimated demand of the poor for poverty reduction [21]. Unfortunately, two-third of all micro financed households engaged in borrowing from multiple organizations and one-third of households had two or more borrowers in Bangladesh [22,23]. Microfinance institutions do not have the profundity of outreach that is needed to meet the demands of the poor people for poverty reduction. Serving the poor in the developing world involves a major financial commitment, as it is expensive to run microfinance program and high transaction costs, small volumes and the high costs of expanding outreach, make it unprofitable to serve the poor for poverty reduction in Bangladesh [24].The study further argued that not more than $5 \%$ of microfinance programs world-wide could become financially viable without subsidy for this grounds microfinance institution cannot achieve its goal in the field of poverty reduction [25].

The study of Ghosh (2006), established that the microfinance operations, including the Grameen Bank's depend substantially on subsidies because of high costs of transaction and monitoring [26]. Such subsidies may imply a transfer of public resources from other public spending, leading to cuts in public health, sanitation and education expenditure. Therefore, microfinance provides small amounts of money and requires borrowers to repay their loans quickly; microfinance may merely function as a consumption stabilizer, reducing the adverse effects of shocks such as natural calamities or seasonal fluctuations, and provides means for taking advantages of very small business opportunities. As a consequence, microfinance may amount to no more than a redistribution of income among the relatively poor, rather than an overall increase in income of the poor. The current reality of microfinance is that the effectiveness of microfinance programs is increasingly challenged by media, public, governments, community leader, social workers and academics.

\section{Methods}

Respondents were 400 out of 279,000 women beneficiaries of microfinance, recruited from the district of Bogra. Cluster sampling refers to dividing the study population into separate areas or groups based on specific features of the population [27]. For this study purpose, a cluster sampling method was deployed. In the first stage of sampling, out of 15, a total number of 10 sub-districts were randomly selected for data collection purposes. In the second stage, from 10 sub-districts, out of 120 , a total number of 40 centres of Grameen Bank (four centres from each sub-district) were selected. For the third stage, the study randomly selected 10 members ( 40 centres $\times 10$ respondents $=400$ respondents) from each centre of Grameen Bank. A list of microfinance beneficiaries from Grameen Bank customer 
service unit was scrutinized during the sample selection. The list detailed names, addresses, and loan received period and helped researcher to determine the respondents and access them easily. This sampling had served to minimize a likelihood of bias in recruiting beneficiaries. A semi-structured questionnaire was designed for data collection. Both close-ended and open-ended questions were employed to collect primary data. One-on-one interviews were conducted to collect data. The collected were analyzed with assistance of a computer- directed program known as
Statistical Package for Social Sciences (SPSS) Version 15.

\section{Findings}

This chapter details the findings of data analysis. The findings begin with the relationship between microfinance and household income, education, employment, housing facilities, health care facilities and women empowerment.

Table 1. Summary of Findings

\begin{tabular}{|c|c|c|c|}
\hline Variables & $\mathrm{N}(\%)$ & Variables & $\mathrm{N}(\%)$ \\
\hline 1. Demographic Characteristics & & Received Healthcare from MFIs & \\
\hline Marital Status & & Yes & $23 \%$ \\
\hline Married & $92 \%$ & No & $77 \%$ \\
\hline Widow & $8 \%$ & 6. House & \\
\hline Involvement with Number of MFIs & & Thatched house & $12 \%$ \\
\hline One MFI & $45.7 \%$ & Tin shade house & $69 \%$ \\
\hline Two MFIs & $40.5 \%$ & Semi-detached & $19 \%$ \\
\hline Three MFIs & $13.8 \%$ & 7. Women Empowerment & \\
\hline & & $\begin{array}{c}\text { Contribution of Women`s in Family Financial Decision } \\
\text { Making }\end{array}$ & \\
\hline 2. Income Per day of Beneficiaries & & Yes & $45 \%$ \\
\hline Income $<$ US $\$ 1$ & $82 \%$ & No & $55 \%$ \\
\hline Income $>$ US $\$ 1$ & $18 \%$ & Women`s Ability to Exercise to Vote & \\
\hline 3. Occupation & & Yes & $20 \%$ \\
\hline Unemployed & $51 \%$ & No & $80 \%$ \\
\hline Small cattle farm & $30 \%$ & $\begin{array}{l}\text { Control Over the use of Microfinance } \\
\text { by Beneficiaries }\end{array}$ & \\
\hline Handicraft & $19 \%$ & Yes & $84 \%$ \\
\hline 4. Education & & No & $16 \%$ \\
\hline No formal education & $69 \%$ & & \\
\hline Formal education & $31 \%$ & & \\
\hline \multicolumn{4}{|l|}{ Technical or Skills Development Training } \\
\hline Not received training & $77 \%$ & & \\
\hline Received training & $23 \%$ & & \\
\hline \multicolumn{4}{|l|}{ 5. Health Care } \\
\hline \multicolumn{4}{|l|}{ Medical Facilities } \\
\hline Specialist doctor & $8 \%$ & & \\
\hline General practitioners & $92 \%$ & & \\
\hline \multicolumn{4}{|l|}{ Latrine } \\
\hline Sanitary latrine & $11 \%$ & & \\
\hline Ring slab & $29 \%$ & & \\
\hline Pit latrine & $33 \%$ & & \\
\hline Don`t use latrine & $27 \%$ & & \\
\hline
\end{tabular}




\section{Discussion}

This chapter includes a discussion and analysis to the findings. Discussion begins with the demographic finding and the relationship between microfinance and the following variables- household income, proper employment, education, adequate health care, nutrition and sanitation, proper housing and women empowerment in Bangladesh.

\section{Household Income}

Income is still an important condition for determining the standard of living. Therefore, the past three decades MFIs have been working to increase the household income for rural poor population in Bangladesh. Income influences other welfare indicators such as food, clothing, proper health care, education, housing, and lack of income deprives people of access to these basic needs [28].The findings from the previous chapter highlighted that there were no significance relationship between the microfinance and increasing the household income in a day, income in month and income in year of the beneficiaries. The household income of the majority beneficiaries were less than US\$1 in the district of Bogra.

The study from Sulaiman and Matin (2008) stated that microfinance alone is largely inadequate to increase the income of the poorest [29]. On the contrary, based on the findings of this study and others [30], microfinance helped to precipitate a declinein incomes, wages, profits, and working conditions in many localities in the poor and transition countries because the space for new entrants is provided only by a decrease of per capita earning capacities. The findings have shown that the income of Grameen Bank beneficiaries was very low and insufficient even to meet the basic needs. This study did not find strong causal link between access to microfinance programs and increases income for the poor women's in the district of Bogra. This strengthens the contention that microfinance programs were ineffective to assist the poor in the district of Bogra. Microfinance may ultimately constitute a new and very powerful institutional barrier to sustainable local economic and social development, and thus also to sustainable poverty reduction [31]. The findings from this study so far has consistently aligned with the views of previous studies mentioned above.

\section{Education}

When it comes to the level of education, there was no significance relationship between microfinance and education qualification of the respondents. While the majority of microfinance borrowers were women, most of them $(69 \%)$ were illiterate, had no formal education, and did have any skill development training or basic knowledge on utilizing the received loan.The study by Khan (2009) argued a number of borrowers taking their children, especially girls, out of school in order to continue making loan payments. Even more recounted their children going hungry the night before a loan payment was due, when they could not afford both food for the family and the following day's payment in
Bangladesh. It was also observed that the loan officers did not supervise the beneficiaries to ensure the proper utilization of the microfinance. An interesting finding was majority of the microfinance beneficiaries (77\%) did not receive any technical or development skill training from the respective microfinance institutions [32].

Many borrowers were expecting that their functioning ability could be enhanced by being provided training in technical aspects and business skills. Due to the void of the training have steered a large number of borrowers to misuse the loans, unable to operate their business, nor do generate income and improve their living standards. As pointed out in the MFI's principle, it was central to provide technical training to inculcate and skills among the beneficiaries. Unfortunately, the microfinance providers took no measures to impart any knowledge pertaining to this trail.

Similar to the findings of Hulme and Arun (2011), the microfinance field staffs were heavily pressurized to achieve the desired financial repayment targets to secure their jobs. In addition, their job performance was mainly measured in terms of credit repayment [33]. Therefore, they ignored the enhancement of professional or skills development for vulnerable women's empowerment, capacity building, and control over loans, poverty reduction and strength needed to improve the standard of living of beneficiaries.

\section{Employment}

Another important variable in mitigating poverty is employment. Employment is a key link between income and poverty reduction [34]. In terms of occupation, there was no significance relationship between microfinance and employment opportunities. Majority of microfinance beneficiaries (51\%) remained unemployed and had no income generating activities to support their living in the district of Bogra, Bangladesh. On the other hand, the rest of them undertook a variety of other occupations including small cattle farm $30 \%$, handicraft, and other petty business were owned by traders grocery shop, hacking, and street vendors.

Dichter (2007) argued that it was becoming quite clear that most microfinance was actually used not so much for income-generating projects, but mainly to facilitate consumption spending [35]. While consumption smoothing is a useful survival technique, this transformation represents a quite dramatic break with the original Grameen Bank's principle. The magnitude of unemployment and underemployment was an unblemished indicator of impoverish conditions faced by the people in this communities.

\section{Health, Nutrition and Sanitation}

Health is an important tenet in our lives, going one step ahead; a good health is a key towards poverty eradication [36]. As presented by the data of this study, most of the microfinance beneficiaries did not have access to modern medical facilities as their income was insufficient. In case of emergency, $92 \%$ relied on general practitioners, few of them 
from specialist doctors and others from local pharmacies, homeopathic doctor, local nurse, hospital compounder or local medical store which quality was widely questioned. In terms of personal hygiene, $33 \%$ of the beneficiaries had accessibility to pit latrines and $27 \%$ of them have not used them, while $29 \%$ are using ring slab, and $10 \%$ of them using sanitary latrines.

Scarcity of nutritious food, lack of appropriate knowledge about hygiene, physical illness and diseases are commonly acknowledged among the beneficiaries as well as their family members. This was noticed and documented in this study. The microfinance beneficiaries could not even consume as much as they could before. They could not even think of having nutritious food and clothes due to the tension of making repayments. This shows that the beneficiaries were deprived from their basic right to food, clothes, health, nutrition and sanitation.

This also indicates that microfinance was not being utilized avidly towards the beneficiaries, in the district of Bogra, Bangladesh. An important point to be highlighted here was $77 \%$ microfinance beneficiaries did not enjoy any healthcare facilities from microfinance institutions. The findings of this study confirmed the arguments presented by Navajas, et al. (2003) and Nayar, et al (2004) in which there was no significant relationship between microfinance programs and health care, nutrition and sanitation facilities in Bangladesh [37, 38].

\section{Housing}

The poverty of the population was reflected in the housing conditions. The housing conditions in Bangladesh have never been satisfactory for rural poor population. The main constraint in housing production was the high cost of housing in relation to incomes, in rural areas. Additionally, the government and MFIs did not provided sufficient housing to satisfy the growing housing needs due to population growth in rural areas. Majority of dwelling units were temporary, not-standard, unsafe, and overcrowded whose structural frame was of bamboo and a few pieces of lumber, usually covered with shan (hemp), a popular thatch material of long dried grass, with plastered mud as walls. However, there was a noticeable feature that a small significant number of beneficiaries had even changed their residences as semi-building and building meanwhile $69 \%$ of the population in the district of Bogra still live by tin made houses [39].

\section{Women Empowerment}

Women empowerment increases women's access to economic resources and opportunities including jobs, financial services, property and other productive assets, and skills development. However, women's bargaining power at the household level was restricted due to their limited access to resources outside the home, low self-esteem, low skills, education, restricted physical mobility and eventually, by the social settings where dominated by males in Bangladesh [40]. Findings from this research unveiled that in the family's financial decision making process, $55 \%$ contribution was not respected. It was also accepted the respondents that they were excluded by their family leaders and low self-esteem attributed to their fragility.

Another remarkable phenomenon was that $80 \%$ of the respondents accepted that their freedom of expression was restrained by their husbands' interferences in times of voting at the local or national elections. It was also found that some of the beneficiaries' husbands manipulate their spouse's freedom and this often leads to further conflicts in the household. In reality, despite having access to credit, majority of female beneficiaries did not have control over the financial assistance. Microfinance by itself could not overcome patriarchal systems of control at the household and community levels, this potential are not always realized [41]. Women's economic participation and empowerment are fundamental to strengthening women's rights and enabling women to have control over their lives and exert influence in society [42].

In Bangladesh's experience, another well-known fact but worth addressing was that microfinance did not contribute considerably to women's bargaining power. They were compelled to surrender nearly $84 \%$ of their investment to their male household members. Additionally, women often face discrimination and persistent gender inequalities, with some women experiencing multiple discrimination by and exclusion in Bangladesh. One important criticism of microfinance was that there was no strong evidence to support the claims that microfinance actually improves the condition of the poverty reduction. The World Bank (2007) reported that the evidence from micro-studies of favourable impacts from direct access of the poor to microfinance was not especially strong among in Bangladeshi women [43].

From the presented above evidence from the findings, it could be summarized that there was a significant relationship between microfinance and housing condition. On the other hand, there were no significant relationship between microfinance and the following variables (household income, education, employment, health, nutrition and sanitation and women empowerment) in the district of Bogra.

\section{Recommendations for Poverty Reduction in Bangladesh}

Over the years, a number of institutional approaches have been applied to reduce poverty from society but poverty could not reduce as an effective manner. In the light of findings, there was insufficient evidence to support the claims of microfinance institutions that they had change totally the well-being of the poor in Bangladesh. A different and alternative policy and programs were highly felt by the microfinance beneficiaries for poverty reduction in rural Bangladesh. To assist the poor, alternative integrated policy initiatives have to be formulated to really help the rural poor in the country.

Social welfare initiatives such as education, health, 
employment, and social security of a country are often designed by its social policies. However, social policy also explicitly deals with redistribution of wealth, protection from risk and social justice [44].In appropriate fiscal policies, mis-targeting, corruption and inefficient delivery of public welfare programs led $45 \%$ of Bangladeshi population living below poverty line.On the other side, MFIs found to be not successful in rural poverty reduction due to lack of evocative vision, absence of commitment that goes beyond manifestos and that could transform the vision into policies and programs, and weak capacities, commercialized intention of the MFIs in Bangladesh [45]. For example, currently, many welfare reform proposals being developed to focus on getting the poor off welfare regardless to whether it is possible to escape poverty or not while many workers are unable to contribute to their families' livelihood in Bangladesh.

A massive reformation would be indispensable in the parliamentary, judiciary, public administration and budgetary process for meaningful poverty reduction and social development. Human rights promotion, public advocacy, capacity building, combined effort to eradicate corruption, and decentralisations of the administration are also to be undeniably concentrated for a sustainable transformation.

In Bangladesh, the both societal and familial lives of microfinance beneficiaries are being severely shattered by natural disaster, since it has been a regular victim of various sporadic natural disasters-flood, and storm surge, flood, drought, riverbank erosion, and landslide. They brought deadly damages to the livelihood activities of microfinance beneficiaries in the district of Bogra. Natural disasters cannot be pre-empted at all, but their damages can be mitigated with effective responses. For effective disaster management programs, the government, local communities, MFIs, private sector, academia, community development workers, neighbouring countries and donor communities could work together for an institutional partnership approach which is viewed as an effective alternative approach.

In the District of Bogra, mostly the poor households have been living in rural areas with limited or no earning opportunities, whereas they suffer unequal treatments. These unfavourable economic conditions could be transformed in future by creating sufficient and gainful opportunities. High rates of employment growth and high rates of economic growth should go hand in hand for a successful poverty reduction. The government and NGOs should helped creating seasonal employment for microfinance beneficiaries through its food support programmes such as the Food for Works Program, and wages labor. To make employment to reduce poverty, the challenge is not only to create jobs, but also to create sustainable working opportunities for earning opportunities.

The very poorest and receivers of microfinance, live in secluded areas struggling with access to food, clothes, shelter, schooling, and healthcare, should be approached with integrated policies to necessitates for integral support mechanism such as social safety nets. The essential tasks needed for such policy formulation should begin with collaboration of governments with private joint venture or MFIs.

Fruitful educational achievements could open more employment opportunities and it would result in reducing poverty. In 2005, Khanam also agreed that, a larger set of employment opportunities and increased wages observed among microfinance beneficiaries due to higher level of educational attainments. The majority of microfinance beneficiaries were not received formal education. Therefore, women's productivity would be enhanced by the provision of formal education since they enjoy a sense better known to new technologies and optimum utility of allocated resources. The accessibility to uninterrupted key services and affordable infrastructure also ensures an efficient poverty reduction. Supply of domestically generated power, potable water, proper housing, marketing facilities and other essential services that are required for sustainable poverty reduction in Bangladesh could be accomplished through community participation with public and private partnerships [46].

In Bangladesh, the poor microfinance beneficiaries are subject to discrimination and it caused devastating impact on their overall mobility. In addition, gender equality is also a serious challenge to development. Gender based unequal treatment has its negative repercussions on the deprived women, societies as a whole.The government of Bangladesh should ensure the equal distribution of public goods and limited resources and justice available for the poor women and marginalised groups through equal treatment. The basic principles of economic and social justice should be kept in mind when reforms are taken place in regard to provision of welfare.

\section{Conclusions}

This study was conducted to evaluate the effect of microfinance programs in the following variable (household income, education, employment opportunities, housing, health, nutrition, and sanitation and women empowerment) in the district of Bogra, Bangladesh.The microfinance program was concerned, ineffective, and not significant relationship with a variety of activities including increase household income, proper education, employment, health care, nutrition and sanitation, women empowerment and finally, poverty reduction in the district of Bogra. Majority of microfinance beneficiaries were illiterate, they misused the borrowed monies and spent the money for personal consumption and healthcare instead of Small and Medium Enterprises (SME) because they lack proper nursing from MFIs to the beneficiaries. The successful implementation of the proposed recommendations is expected to reduce poverty and improve of living standard of Bangladeshi poor citizenry and become a model for many other similar countries.In conclusion, the multi-faceted nature of poverty requires a 
multi-dimensional approach to poverty reduction based on the development of human potential, creativity and resourcefulness of the poor and building upon their resources, capabilities and survival skills.

\section{REFERENCES}

[1] Swope, T. (2010). Microfinance and poverty reduction. Rollins Undergraduate research Journal, 2(1), 1-62.

[2] B.B.S. (2012). Bangladesh Bureau of Statistics. Report on welfare monitoring survey. Retrieved from http://www.bbs.gov.bd

[3] Swope, T. (2010). Microfinance and poverty reduction. Rollins Undergraduate research Journal, 2(1), 1-62.

[4] Ahmad, S. (2009). Microfinance Institutions in Bangladesh: Achievements and challenges. Managerial Finance,35(12), 999-1010.

[5] Haque, S., \&Yamao, S. (2008). Could microfinance alleviate rural poverty? A case study of Bangladesh. World Science of Academy and Technology, 46(3), 648-656.

[6] Ullah, A. K., \&Routray, J. K. (2007). Rural poverty reduction through NGO interventions in Bangladesh: How far is the achievement? International Journal of Social Economics, 34(4), 237-248.

[7] Ahmad, S. (2009). Microfinance Institutions in Bangladesh: Achievements and challenges. Managerial Finance,35(12), 999-1010.

[8] Hoque, S. (2004). Micro-credit and the reduction of poverty in Bangladesh. Journal of Contemporary Asia, 34(1), 21-32.

[9] Karnani, A. (2007). Employment, not microcredit, is the solution. Ross School of Business Working Paper Series, Working Paper No. 1065. Stephen M. Ross School of Business at the University of Michigan: USA.

[10] Alam, C. M., \& Miyagi, K. (2004). An approachable analysis of micro-enterprises in Bangladesh. Department of International Studies Working Paper No-8. Hagi International University: Japan

[11] Mannan, M. A. (2007). Alternative microfinance models in Bangladesh: A comparative analysis between Grameen Bank and the Social investment Bank and myths and realities. Paper presented in First International Islamic Conference on Inclusive Islamic Financial Sector Development, April, 17-19. Brunei Darussalam.

[12] Murdoch, J. (2008). How could the poor afford microfinance? Financial access initiative. Wagner Graduate School, New York University, New York: USA

[13] Mahajan, V. (2005). From microfinance to livelihood finance. Economic and Political Weekly. Retrieved from http://www.en.wikipedia.org/wiki/Economic and Political Weekly.

[14] Brau, J., \&Woller, G. M. (2004). Microfinance: A comprehensive review of the existing literature. Journal of Entrepreneurial Finance and Business Venture, 9(1), 1-26.
[15] Pollin, R. (2007). Microcredit: False hopes and real possibilities. Retrieved from http://www.fpif.org/fpiftxt/4323.p

[16] Banerjee, A., Duflo, E., Glennerster, R., \&Kinnan, C. (2009). The miracle of microfinance? Evidence from a randomized evaluation. Retrieved from http://econ-www.mit.edu/files/4162.

[17] Navajas S., Conning J., Gonzalez, V. C. (2003). Lending technologies, competition and consolidation in the market for microfinance in Bolivia. Journal of International Development, 15(6), 747-770.

[18] Navajas S., Conning J., Gonzalez, V. C. (2003). Lending technologies, competition and consolidation in the market for microfinance in Bolivia. Journal of International Development, 15(6), 747-770.

[19] Ditcher, T. (2006). Hype and hope: The worrisome state of microfinance movement. Retrieved from

http://www.microfinancegateway.org/content/article/detail/3 1747 ?

[20] Mosely, P., \& Rock, J. (2004). Microfinance, labor markets and poverty in Africa: A study of six institutions. Journal of International Development, 16(3), 467-500.

[21] Littlefield, E., \& Rosenberg, R. (2004). Microfinance and the poor: Breaking down the walls between microfinance and the formal financial system. Finance \& Development, 41(2), $38-40$.

[22] Haque, S., \&Yamao, S. (2008). Could microfinance alleviate rural poverty? A case study of Bangladesh. World Science of Academy and Technology, 46(3), 648-656.

[23] Shillabeer, M. G. (2008). Poverty reduction or poverty traps? Micro-credits and vulnerability in Bangladesh. Disaster Prevention and Management, 17(3), 396-409.

[24] Claessens, S. (2005). Access to financial services: A review of the issues and public policy objectives. World Bank Research Working Paper No-3589. Washington, DC: World Bank.

[25] International Monetary Fund. (2005). Microfinance: A view from the fund. Retrieved from http://www.imf.org/external/np/pp/eng/2005/012505.p df

[26] Ghosh, J. (2006). Development as a noble cause. Retrieved from http;//www.southasia. oneworld.net/view/142067/1/2235.

[27] Chadwick, B. A., Bahr, H.M., \& Albrecht, S.L. (1984). Social sciences research methods. New Jersey: Prentice Hall.

[28] Nawaz, S. (2010). Microfinance and poverty reduction: Evidence from a village study in Bangladesh. Journal of Asian and African Studies, 45(6), 670-683.

[29] Sulaiman, M., \&Matin. (2008). Making microfinance work for the extreme poor: Evidence and experience from Bangladesh. Finance for the Poor, 9(1), 1-7.

[30] Davis, M. (2006). Planet of slums. London: Verso.

[31] Bateman, M., \& Chang, H. J. (2009). The microfinance illusion. Faculty of Economics, University of Cambridge: UK

[32] Khan. S. (2009). Poverty reduction efforts: Does microcredit help?SAIS Review, 29(2), 147-157. 
[33] Hulme, D., \&Arun, T. (2011). What's wrong and right with microfinance? Economic \& Political Weekly, 46(48), 23-26.

[34] United Nations Development Programme. (2009). Human development report. Retrieved fromhttp://www.un.org

[35] Dichter, T. (2007). A second look at microfinance: The sequence of growth and credit in economic history. Centre for Global Liberty and Prosperity, CATO Institute: USA.

[36] Harper, M. (2007). Microfinance and farmers: Do they fit? In T. Dichter\& M. Harper (Eds.), What's wrong with microfinance? London: Practical Action Publishers.

[37] Navajas S., Conning J., Gonzalez, V. C. (2003). Lending technologies, competition and consolidation in the market for microfinance in Bolivia. Journal of International Development, 15(6), 747-770.

[38] Nayar, K.R., Kyobutungi, C., \&Razum, O. (2004). Self-help: What future role in health care for low and middle-income countries? International Journal for Equity in Health, 3(1), 1-10.

[39] Odoom, F. O. (2009). Has the habitat for humanity housing scheme achieved its goals? A Ghanaian case study. Journal of Housing and the Built Environment, 24(1), 67-84.

[40] Panday, P.K. (2008). Representation without participation:
Quotas for women in Bangladesh. International Political Science Review, 29(4), 489-512.

[41] Ahmad, S. M., Chowdhuri, M., \&Bhuiya, A. (2001). Microcredit and emotional well-being: Experience of poor rural women from Matlab, Bangladesh. World Development, 29(11), 1957-1966.

[42] Ministry for Foreign Affairs, Sweden. (2010). On equal footing: Policy for gender equality and the rights and role of women in Sweden's international development cooperation 2010-2015. Stockholm: Sweden.

[43] World Bank. (2007). Finance for all? Policies and pitfalls in expanding access. Washington DC: World Bank

[44] Ortiz, I. (2007). Social policy: National development strategies policy notes. United Nations Department of Economic and Social Affairs, New York: USA.

[45] Sobhan, R. (1998). How bad governance impedes poverty alleviation in Bangladesh. Organization for Economic Co-operation and Development (OECD). Paris: France.

[46] Panggabean, A.T.P. (2006). Expanding access to basic services in Asia and the Pacific region: Public-private partnerships for poverty reduction. Asian Development Bank, Manila: Philippines. 